\title{
ASSESSMENT OF METAL CONTAMINATION IN COASTAL SEDIMENTS OF THE LÉVRIER BAY AREA, ATLANTIC OCEAN, MAURITANIA
}

\author{
Mohamed El Houssein LEGRAA ${ }^{1}$, Abdelkader MOHAMED SALECK ${ }^{2}$, \\ Ali YAHYA DARTIGE ${ }^{3}$, Mohamed Lemine CHEIKH ZAMEL ${ }^{3}$, Mohamed Mahmoud \\ Ould ABIDINE ${ }^{I}$, Hassan ERRAOUI ${ }^{4}$ and Zeinebou SIDOUMOU ${ }^{I}$
}

DOI: 10.21163/GT_2019. 141.05

\begin{abstract}
:
This work presents an assessment of marine pollution due to heavy metals accumulated in surface sediments collected from the Lévrier bay coastline in NW Atlantic, Mauritania. The samples were subjected to $\mathrm{HCl}$ and $\mathrm{HNO} 3$ digestion, and an atomic absorption spectrophotometer was used to determine the concentrations of all metals $(\mathrm{Cd}, \mathrm{Pb}, \mathrm{Cu}$ and $\mathrm{Zn}$ ) with the exception of $\mathrm{Hg}$ that was analysed by DMA-80 Direct Mercury Analyzer. The ranking of the metals at all studied sites was $\mathrm{Al}>\mathrm{Zn}>\mathrm{Cu}>\mathrm{Pb}>\mathrm{Cd}>\mathrm{Hg}$, and all the sediments samples displayed lower concentrations than the calculated worldwide mean of unpolluted sediments. The data were classified according to seasons. . Eight common pollution indices (i.e. EF, Igeo, QoC(\%), CF, SPI, PLI, $\mathrm{C}_{\mathrm{d}}$ and PERI)were applied to ascertain the sediment quality. The enrichment (EF) factor resulting from $\mathrm{Pb}, \mathrm{Cu}$ and $\mathrm{Zn}$ were $<1$ in surface sediments at all sampling sites and for $\mathrm{Cd}$ at Cap Blanc, indicating no enrichement. EF values in COMECA and Baie de l'Etoile for $\mathrm{Cd}$ were $1<\mathrm{EF}<3$, indicating a low enrichment. EF values for $\mathrm{Cd}$ at IMROP were $3<\mathrm{EF}<5$ indicated a moderate enrichment. The value of the geoaccumulation (Igeo) factor from all metals analysed was less than 0 in all sampling sites, which classified the sediments as uncontaminated.The value of contamination (CF) factor for all elements analyzed was lower than 1 across all sampling sites, implying a low contamination.The values of Sediment Pollution (SPI) Index were $0<\mathrm{SPI}<2$, indicating a natural status of sediments in COMECA, Baie de l'Etoile and Cap Blanc. The SPI values at IMROP were $2<\mathrm{SPI}<5$, which showed a low pollution of sediments on this site. The value of the pollution load (PLI) index was $<1$, which indicated that no metal pollution existed in sediments in all studied sites. The values of the contamination degree $\left(\mathbf{C}_{d}\right)$ were $<6$ in all sampling sites, indicating a low degree of contamination. The values of the Potential Ecological Risk (PERI) index were $21.5<$ PERI $<28.4$ in all sampling sites, indicating a low ecologic risk. These results provide an important reference for future comparisons in the West African sub-region on the state of contamination of marine and coastal areas.
\end{abstract}

Key-words: Heavy metals, Pollution indexes, Sediments, Lévrier bay, Mauritania.

\footnotetext{
${ }^{I}$ Department of Biology, Faculty of Science and Technology, UR / EBIOME, University of Nouakchott AL Aasriya, Mauritania legraahoussein@yahoo.fr, mintsidoumou@yahoo.fr , hmd108@yahoo.fr

${ }^{2}$ Department of Geology, Faculty of Science and Technology, University of Nouakchott AL Aasriya, Mauritaniasaleckakm@yahoo.fr

${ }^{3}$ National Office for Sanitary Inspection of Fisheries and Aquaculture Products (ONISPA), Mauritaniaalydartige@yahoo.fr, cheikhzamel@gmail.com

${ }^{4}$ Department of Earth Sciences, Faculty of Science and Technology, Laboratory of Environmental Geosciences, Abdelmalek Essaidi University, Tétouan, Morocco h.erraioui@fstt.ac.ma
} 


\section{INTRODUCTION}

The Mauritanian coastline is under increasing anthropogenic pressure from the land. Urbanization, fishing, port facilities, oil exploration and exploitation all present potential threats to the richness of the fishery resources. All these activities are likely to generate pollution, chronic or accidental.

The Lévrier bay is home to important fishing and industrial activities. It is considered the area where the country's fishing and industrial activities are most intense. This situation is at the origin of disturbances of the marine environment; mainly due to industrial discharges loaded with organic and inorganic pollutants such as trace metals, some of which may be toxic to marine fauna and flora (L. Chouba et al., 2007). Coastal areas can be seriously affected by chemical contamination due to the long hydrologic residence time and consequent long-term retention of pollutants and atmospheric deposits that originate from (Alharbi \& El-Sorogy, 2017; Liu et al., 2018; Zhang et al., 2017).

Introduction of heavy metals into the marine environment induces their accumulation in sediments. Many studies have dealt with heavy metal pollution worldwide in coastal areas discharge, oceanic dumping and aeolian processes along littoral zones. Most of these studies have used heavy metal analysis in sediments(Ghasemi, Moghaddam, Rahimi, Damalas, \& Naji, 2018; Liu et al., 2018; Zhang et al., 2017). There are several methods for evaluating metal pollution in sediment and for risks caused by trace metals (Bastami et al., 2015; Izah, Bassey, \& Ohimain, 2017; Sharifinia, Taherizadeh, Namin, \& Kamrani, 2018; Vu et al., 2017; Yu et al., 2017).

The purpose was to provide preliminary information on environmental conditions and risks from metal contamination, and to evaluate the spatial and temporal variability of data covering 32 months during the cold and hot season. We also verified whether metal concentrations did were not significantly higher in sediment of the Lévrier bay, a coastal water located on the north shoreline of Mauritania. The main objectives of the present study were to (a) evaluate the spatial and temporal distribution of trace metals in surface sediments impacted by anthropogenic activities, (b) compare the level of pollution in the Lévrier bay coastal area with neighboring coasts and coasts elsewhere in the world, (c) compare heavy metals concentrations with the sediment quality guideline values and estimate their possible effects on the aquatic life of the study area (d) determine the ecological risk of $\mathrm{Zn}, \mathrm{Pb}, \mathrm{Cu}$, and $\mathrm{Cd}$ in surface sediments using pollution indices and (e) make recommendations in terms of management to decision-makers.

\section{MATERIALS AND METHODS}

\subsection{Study area}

The Mauritanian coastline covers nearly $720 \mathrm{~km}$. The coastal waters are the scene, among others, of two major phenomena. The first one is the occurrence of the thermal front resulting of the meeting of the two main currents of the zone namely the Canary current and the northern equatorial counter-current commonly called the Guinea current. The second one is the coastal upwelling that is one of the most important oceanographic factors in shaping the hydrological regime and structures of water bodies in northwestern Africa. It is at the origin of a high abundance of phytoplankton in the system which is the basis of the complex food web of the marine environment. This coastal Upwelling explains in part the very great wealthin species of the Mauritanian waters which have a reputation as being one of the richest water in fish in the world. The Lévrier Bay, located in the extreme north-west 
of Mauritania, is the only large natural bay on the Mauritanian coast and one of the largest on the west coast of Africa (Wagne, BRAHIM, DARTIGE, \& SÉFRIOUI, 2011). The bay is home to important fishing and industrial activities. It is considered the area where the fishing and industrial activities of the country are most intense. The bay provides shelter to four different ports including that of the most important industrial and mining society of Mauritania (IMSM). The city of Nouadhibou, the economic capital of the country, has more than forty fishing companies specialised in fish processing. This situation is at the origin of disturbances of the marine environment; mainly due to industrial discharges loaded with organic and inorganic pollutants such as trace metals (cadmium, lead, mercury, etc.) which are often toxic to marine fauna and flora(Lassaad Chouba \& Mzougui-Aguir, 2006). Studies on the hydrology of Mauritanian marine waters have identified four major seasons, the most important of which are the cold (January to May) and hot (August to October) seasons interspersed with two inter-seasons, the cold-hot season (June to July) and the hotcold season (November to December)(Wagne, 2013; Wagne et al., 2011).

We conducted a seasonal survey of six heavy metals $(\mathrm{Cd}, \mathrm{Pb}, \mathrm{Hg}, \mathrm{Cu}, \mathrm{Zn}$ and $\mathrm{Al}$ ) accumulated in sediments during 32 months, from January 2013 to October 2016 during both the cold and the hot season at four stations located in the Lévrier bay coast (Fig. 1).

Sites were positioned along transects using a Garmin 585 global positioning system (GPS) with a resolution of about $3.5 \mathrm{~m}$ :

- Baie de l'Etoile $\left(21^{\circ} 02^{\prime} 19.2^{\prime \prime}\right.$ N. $\left.17^{\circ} 01^{\prime} 36.8^{\prime}, \mathrm{W}\right)$; is located in northwestern Africa. It is the only African bay to the north to be characterized by a significant area of salt marshes spartines;

- Cap Blanc ( $20^{\circ} 46^{\prime} 47.58^{\prime \prime}$ N. $\left.17^{\circ} 03^{\prime} 30.24^{\prime \prime} \mathrm{W}\right)$; Nature Reserve, home to one of the world's largest threatened colonies of monk seals;

- COMECA's sampling point is located outside Cansado Bay and more specifically on the southwest side of Cansado Point not far from the oil port and near the metallurgical company “COMECA" (20 $50^{\prime}$ ' $24.7^{\prime}$ ' N. $17^{\circ} 02^{\prime}$ '03.6”' W);

- IMROP's sampling point is located in the southeast of Cansado bay (20 $51^{\prime} 26.2^{\prime}$ ', N. $17^{\circ} 01^{\prime} 52.0^{\prime}$ 'W). It is the site of all the urban discharges of the bay, in particular the Cansado effluents containing domestic sewage.

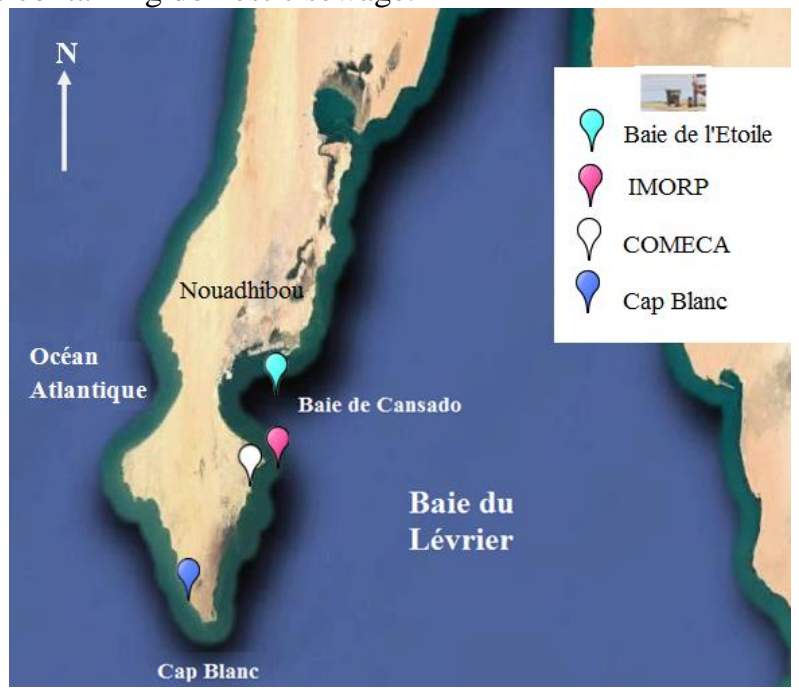

Fig. 1. Location of the study area and sampling sites 


\subsection{Trace metal-based indices}

To assess the quality of the sediments collected in this work, we used the Enrichment factor (EF), Quantification of contamination QoC (\%), Contamination factor (CF), Geoaccumulation index (Igeo), Sediment Pollution Index (SPI), contamination degree $\left(\mathrm{C}_{\mathrm{d}}\right)$, potential ecological risk index (PERI) and pollution load index (PLI). These indices are the most common quantitative methods to assess pollution compared to the concentrations of the elements in the background samples taking into account the bioavailability of the various trace elements( $\mathrm{Li}$ et al., 2013). The abbreviations, terminology, algorithms and descriptions of metal pollution indices used in this study are listed in Table 1.

Table 1.

Pollution indices, abbreviations, algorithms, descriptions and terminology

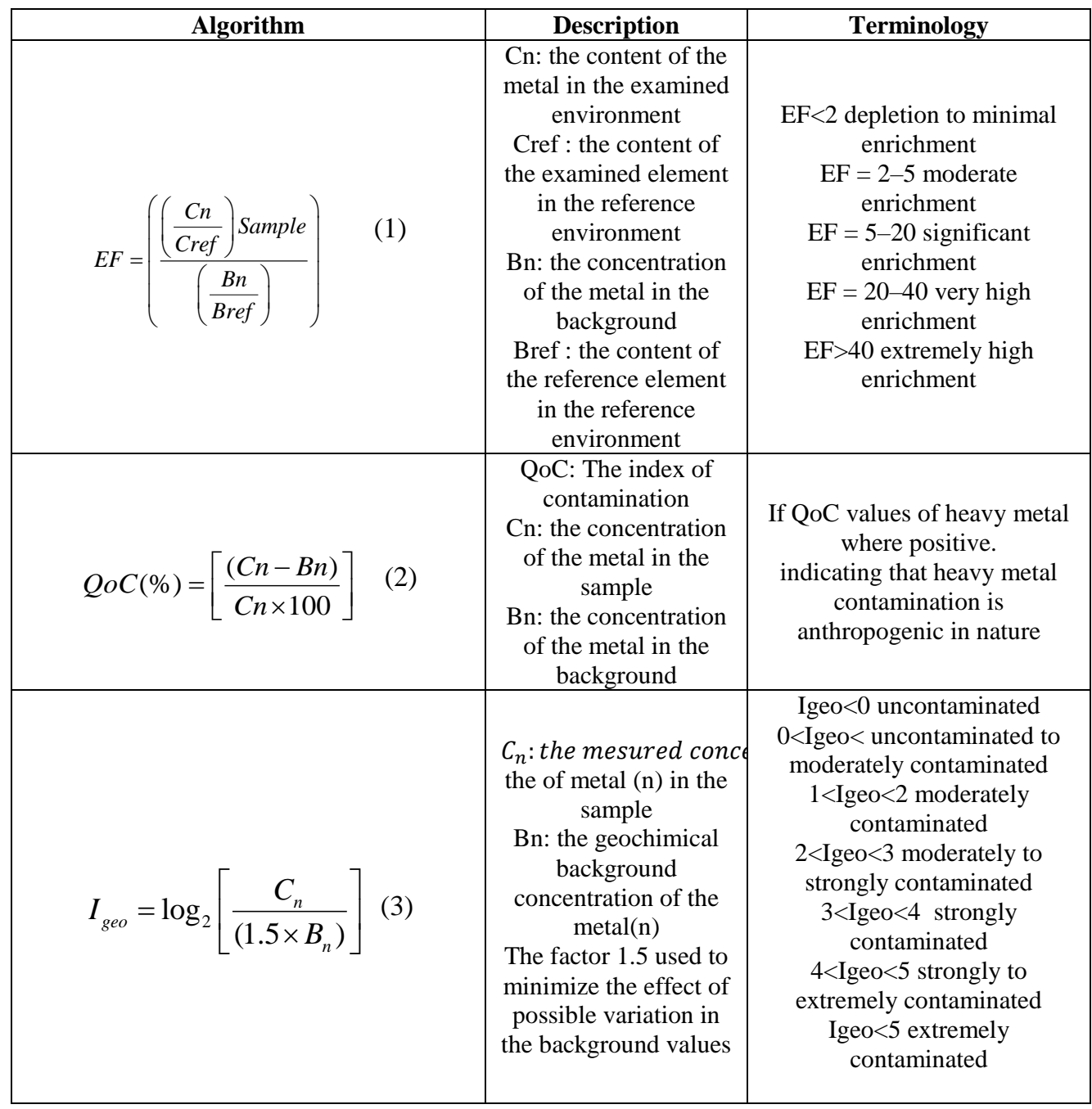




\begin{tabular}{|c|c|c|}
\hline$C F=\frac{C h}{C_{f}^{i}}$ & $\begin{array}{c}\text { n: number of heavy } \\
\text { metals } \\
\text { CF: contaminant } \\
\text { factor } \\
\text { Ch: heavy metal } \\
\text { concentration } \\
\text { Cs: heavy metal } \\
\text { background reference } \\
\text { values }(\mathrm{Zn}=64 \text {. } \\
\mathrm{Cu}=26 . \mathrm{Pb}=10 . \\
\mathrm{Cd}=0.16)\end{array}$ & $\begin{array}{c}\mathrm{CF}<1 \text { low contamination } \\
1<\mathrm{CF}<3 \text { moderate } \\
\text { contamination } \\
3<\mathrm{CF}<6 \text { considerable } \\
\text { contamination } \\
\mathrm{CF}>6 \text { very high } \\
\text { contamination }\end{array}$ \\
\hline$P L I=\sqrt[n]{\left(C F_{1} \times C F_{2} \times C F_{3} \ldots \ldots \times C F_{n}\right)}$ & $\begin{array}{l}\text { n: number of heavy } \\
\text { metals } \\
\text { CF: contaminant } \\
\text { factor }\end{array}$ & $\begin{array}{l}\text { PLI }>1 \text { metal pollution is } \\
\text { present } \\
\text { PLI }<\text { There is no metal } \\
\text { pollution }\end{array}$ \\
\hline$S P I=\frac{\sum\left(F E_{m} \times W_{m}\right)}{\sum W_{m}}$ & $\begin{array}{c}\text { EF: ratio between } \\
\text { sediment total content } \\
\text { in a given sample and } \\
\text { average shale } \\
\text { concentration of a } \\
\text { metal } m \text {; } \\
\text { W: toxicity weight of } \\
\text { metal } m(\mathrm{Zn}=1 . \mathrm{Cu}=2 . \\
\mathrm{Pb}=5 . \mathrm{Cd}=300)\end{array}$ & $\begin{array}{c}0<\text { SPI }<2 \text { natural sediments } \\
2<\text { SPI }<5 \text { low polluted } \\
\text { sediments } \\
2<\text { SPI }<10 \text { moderately } \\
\text { polluted sediments } \\
10<\text { SPI }<20 \text { highly polluted } \\
\text { sediments } \\
\text { SPI }>20 \text { dangerous sediments }\end{array}$ \\
\hline$C_{d}=\sum_{i=1}^{n} C F_{i}$ & $\begin{array}{l}\mathrm{C}_{\mathrm{d}} \text { : sum of the } \\
\text { contaminant factor } \\
(\mathrm{CF})\end{array}$ & $\begin{array}{c}\mathrm{C}_{\mathrm{d}}<6 \text { low degree of } \\
\text { contamination } \\
6<\mathrm{C}_{\mathrm{d}}<12 \text { moderate degree of } \\
\text { contamination } \\
12<\mathrm{C}_{\mathrm{d}}<24 \text { considerable } \\
\text { degree of contamination } \\
\mathrm{C}_{\mathrm{d}}>24 \text { high degree of } \\
\text { contamination }\end{array}$ \\
\hline $\begin{array}{l}P E R I=\sum E_{r}^{i} \\
E_{r}^{i}=T_{r}^{i} \times \mathrm{C}_{f}^{i}\end{array}$ & $\begin{array}{c}T_{r}^{i}: \text { toxicity coefficient } \\
(\mathrm{Zn}=1 . \mathrm{Cu}=\mathrm{Pb}=5 . \\
\mathrm{Cd}=30 . \mathrm{Hg}=40) \\
\mathrm{CF}: \text { contaminant } \\
\text { factor }\end{array}$ & $\begin{array}{c}\text { PERI }<95 \text { low potential } \\
\text { ecologic risk } \\
95<\text { PERI }<190 \text { moderate } \\
\text { ecologic risk } \\
\text { 190<PERI }<380 \text { considerable } \\
\text { ecologic risk } \\
\text { PERI }>380 \text { very high ecologic } \\
\text { risk } \\
\end{array}$ \\
\hline
\end{tabular}

\section{3. Sampling and analytical procedure}

Sediment samples were taken from the shoreline at low tide using PVC tubes with an internal diameter of $58 \mathrm{~mm}$ (quantity $132 \mathrm{ml}$ ). An effort was made not to disturb the edges of the sample and to transfer all of the core into glass bottles (maroon colour) for heavy metal analyzes (including $\mathrm{Al}$ as a marker) or polyethylene bags for granulometry using a stainless steel spatula. The samples were then kept whole without sieving. Then kept refrigerated at $4-10^{\circ} \mathrm{C}$ for $6-48$ hours and frozen at $-50^{\circ} \mathrm{C}$ after arrival at the laboratory. Samples were mineralized in closed Teflon bombs. Weigh precisely about $0.2 \mathrm{~g}$ of dry weight to be analyzed; $10 \mathrm{ml}$ of concentrated HNO3 nitric acid (for analysis) was added; 
the reactors were hermetically closed and left at room temperature for at least 1 hour. They are then heated by microwave according to a well-defined program.

The analysis of $\mathrm{Cd}, \mathrm{Pb}, \mathrm{Cu}, \mathrm{Zn}$ and $\mathrm{Al}$ was done by the graphite furnace method and the $\mathrm{Hg}$ analyzes were made by a DMA-80 Direct Mercury Analyzer. At the end of the neutralization, the mineralizer was poured into a $50 \mathrm{~mL}$ Teflon tube which was supplemented with ultrapure water to the required volume and filtered. This procedure was validated by performing the same extraction on a standard HISS-1 certified sediment (National Research Council of Canada, certified reference materials, marine sediments) and the results obtained were compared to the certified values in Table 2. All samples were run in triplicate and all elements were subsequently expressed in mg kg-1 dry weight.

Table 2.

Measured and certified values of trace metals and detection limits $\left(\mathrm{mgkg}^{-1} \mathrm{DW}\right)$ in the sediments standard reference material BCR16-ERM278K.

\begin{tabular}{|c|c|c|c|c|c|c|}
\hline & $\mathbf{C d}$ & $\mathbf{P b}$ & $\mathbf{H g}$ & $\mathbf{C u}$ & $\mathbf{Z n}$ & $\mathbf{A L}$ \\
\hline Measured & $17 \pm 1$ & $590 \pm 30$ & $8.4 \pm 1$ & $800 \pm 40$ & $2983 \pm 100$ & $7.3+0.5$ \\
\hline Certified & $18 \pm 0.5$ & $609 \pm 14$ & $8.6 \pm 0,4$ & $838 \pm 16$ & $3060 \pm 60$ & --- \\
\hline Detection limits & 0.02 & 0.26 & 0.006 & 0.25 & 0.29 & --- \\
\hline
\end{tabular}

\subsection{Statistical analysis}

All data were statistically processed in STATISTCA ver. 6, SPSS for Windows version 20.0 (2008) and the graphics were drawn in ArcGis 10.3 and OriginPro 8. Heavy metal concentrations in sediments were compared to sediment quality standards, such as, ISQGS and USEPA, to illustrate the state of pollution in the study area. To assess the ecological health risks of trace metals in the study area, chemical pollution indices were also calculated.

\section{RESULTS AND DISCUSSION}

\subsection{Trace metals concentration in superficial sediments at Lévrier bay}

\subsubsection{Environmental gradients}

Samples taken from the various sites in the Lévrier bay consist for up to $43 \%$ of sand $(63 \mu \mathrm{m}-2 \mathrm{~mm})$ and for $16 \%$ of silt $(2-63 \mu \mathrm{m})$. Samples taken at Cap Blanc and COMECA were mainly made up of sand (55 and $45 \%$, respectively) the grain size of which varied between $63 \mu \mathrm{m}$ and $2 \mathrm{~mm}$. These two sites, therefore, consist of rather homogeneous sand but with a marked discontinuity composed of silt at Cap Blanc (35\%) and COMECA $(22 \%)$. 
Samples taken at the Baie de l'Etoile and IMROP contained the lowest levels of silt (2 and $2.7 \%$, respectively) the grain size of which one varied between $2 \mu \mathrm{m}$ and $63 \mu \mathrm{m}$. The intense mining activity for about sixty years would be at the origin of this enrichment in fine materials of this place (Maigret, J, 1972). As reported in many studies, decreased concentrations of heavy metal in sediments are strongly and positively correlated to grain size. Thus, a high level of concentration of heavy metals is generally associated with the fine-grained material $(<63 \mu \mathrm{m})$ compared with size grains $>63 \mu \mathrm{m}$, since the size of their surfaces has an influence on the collection and transport of inorganic constituents (Krauskopf, 1955; Romankevich, 1984).

\subsubsection{Variation of heavy metal concentrations in sediments}

Mean concentrations of the heavy metals (mean \pm SEM) in sediments of the Lévrier bay by individual sites are presented in table 3 .

The highest $\mathrm{Zn}$ concentration of $1.900 \pm 0.620 \mathrm{mgkg}-1$ (DW) was found at Cap Blanc and the lowest values were observed at IMROP (1.219 \pm 0.424 . mgkg-1 DW). The highest and lowest $\mathrm{Cu}$ concentrations were observed at Baie de l'Etoile and COMECA $(0.590 \pm 0.007$ and $0.084 \pm 0.003 \mathrm{mgkg}-1 \mathrm{DW}$, respectively). The highest concentrations of $\mathrm{Pb}$ were found at COMECA $(1.671 \pm 0.534 \mathrm{mgkg}-1 \mathrm{DW})$ and the lowest concentrations were found Cap Blanc $(0.251 \pm 0.111 \mathrm{mgkg}-1 \mathrm{DW})$. For Cd, Baie de l'Etoile exhibited the highest concentration $(0.130 \pm 0.070 \mathrm{mgkg}-1 \mathrm{DW})$ and the lowest concentrations were observed at Cap Blanc $(0.076 \pm 0.021 \mathrm{mgkg}-1 \mathrm{DW})$. However, the $\mathrm{Hg}$ values were the lowest among the metals analyzed regardless of the sampling site. The ranking of the heavy metals in the sediments of the Lévrier bay was $\mathrm{Al}>\mathrm{Zn}>\mathrm{Cu}>\mathrm{Pb}>\mathrm{Cd}>\mathrm{Hg}$ (table. 3).

Table 3.

Concentraions of heavy metal (mean \pm Standard deviation: $\mathrm{mg} / \mathrm{kg} \mathrm{DW}$ ) in sediments for the studied sites

\begin{tabular}{|l|c|c|c|c|c|c|}
\hline Sites & Cd & Pb & Hg & Cu & Zn & Al \\
\hline CO & $0.090 \pm 0.018$ & $1.671 \pm 0.534$ & $0.016 \pm 0.002$ & $0.084 \pm 0.003$ & $1.349 \pm 0.011$ & $3.038 \pm 0.988$ \\
\hline BE & $0.130 \pm 0.070$ & $1.000 \pm 0.400$ & $0.017 \pm 0.002$ & $0.590 \pm 0.007$ & $1.283 \pm 0.045$ & $3.113 \pm 1.023$ \\
\hline CB & $0.076 \pm 0.021$ & $0.251 \pm 0.111$ & $0.020 \pm 0.002$ & $0.573 \pm 0.083$ & $1.900 \pm 0.620$ & $3.635 \pm 0.240$ \\
\hline $\mathrm{IM}$ & $0.082 \pm 0.012$ & $0.805 \pm 0.028$ & $0.019 \pm 0.002$ & $0.352 \pm 0.008$ & $1.219 \pm 0.424$ & $0.886 \pm 0.009$ \\
\hline
\end{tabular}

Heavy metal concentrations in superficial sediments varied between cold and hot seasons (Fig.2), with increased $\mathrm{Cd}$ and $\mathrm{Hg}$ concentrations samples collected during the cold season at all sampling sites and for $\mathrm{Al}$ in the samples taken from COMECA and Baie de l'Etoile. During the hot season, the concentrations of $\mathrm{Pb}, \mathrm{Cu}$ and $\mathrm{Zn}$ were higher at all sampling sites, and also for Al taken at Cap Blanc and IMROP. The discharge of domestic and industrial wastewater at sea containing metals such as $\mathrm{Cd}, \mathrm{Cu}$ and $\mathrm{Zn}$, may provide a dominant and constant input into the sediments of Lévrier bay, thus masking the natural seasonal patterns. 
The absence of significant variations in the concentration of metals in surface sediments between sampling dates can be explained by deposits (of natural and / or anthropogenic elements) and post-depositional remobilization processes, with modification of the diagenetic activity, likely to influence the concentrations. (with or without a seasonal cycle) (Ridgway \& N.B. PRICE, 1987). However, many factors related to the natural variability during the seasons in the physical and chemical characteristics of sediments (especially between cold and hot seasons) can also strongly affect the retention capacity of heavy metals and thus the concentration of metals in the surface sediments.
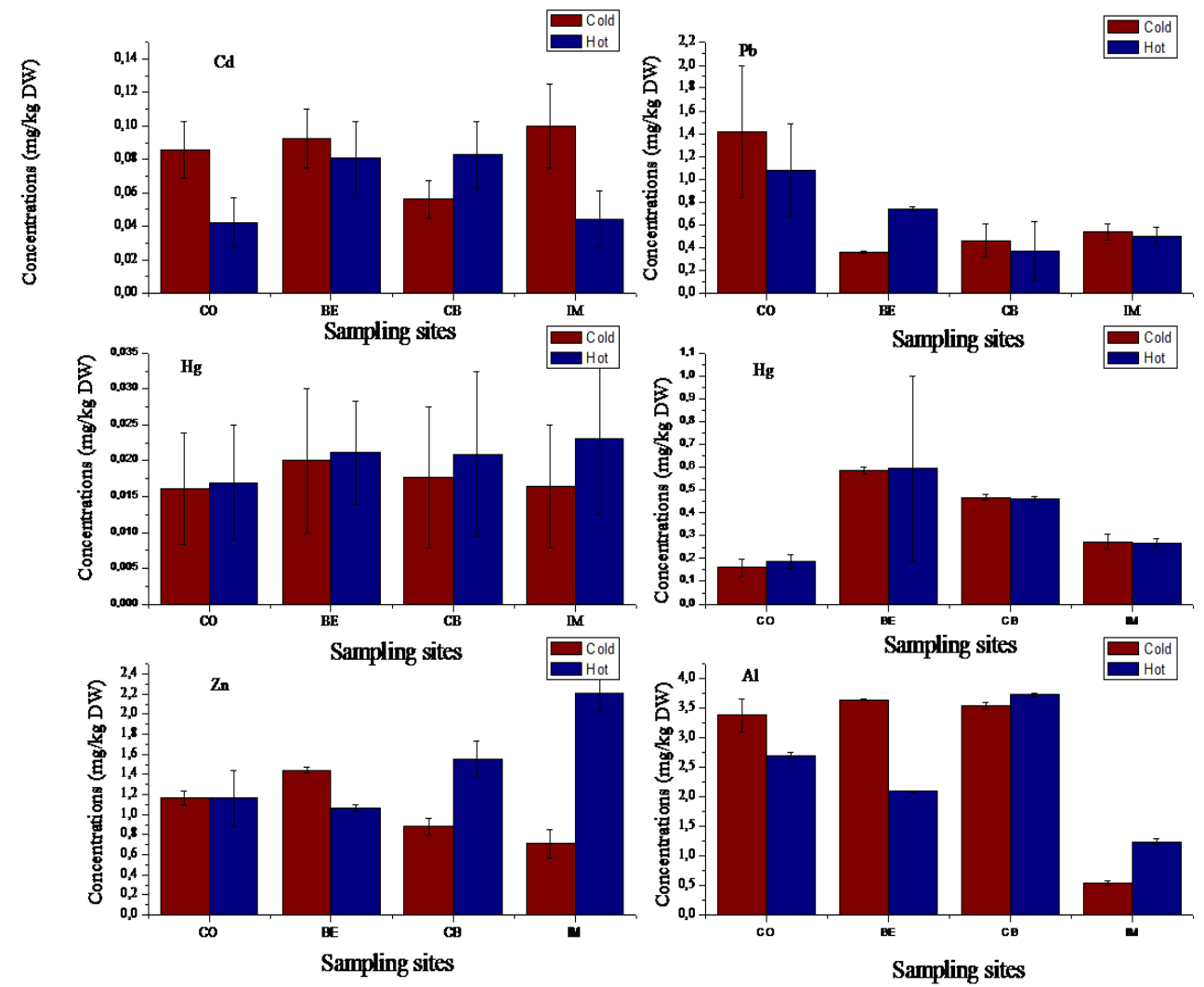

Fig. 2. Heavy metal concentrations in sediments for the studied sites and seasons.

The average concentrations of metals analysed in this study and previous work on the northwest Atlantic coasts are summarized in Table 4. The average concentrations of all analyzed heavy metals in this study are significantly lower than values for other areas of the sub-region. 
Table 4.

Comparison of trace metal concentration in sediments at the Lévrier bay and other areas along the North West Atlantic coast

\begin{tabular}{|c|c|c|c|c|c|c|c|}
\hline $\begin{array}{l}\text { Sampling } \\
\text { sites }\end{array}$ & Cd & $\mathbf{P b}$ & Hg & $\mathrm{Cu}$ & $\mathbf{Z n}$ & Al & Reference \\
\hline \multicolumn{8}{|c|}{ Mauritania } \\
\hline Comeca & $0.090 \pm 0.018$ & $1.671 \pm 0.534$ & $0.016 \pm 0.002$ & $0.084 \pm 0.003$ & $1.349 \pm 0.011$ & $3.038 \pm 0.988$ & $\begin{array}{l}\text { Present } \\
\text { work }\end{array}$ \\
\hline BaieEtoile & $0.130 \pm 0.070$ & $1.000 \pm 0.400$ & $0.017 \pm 0.002$ & $0.590 \pm 0.007$ & $1.283 \pm 0.045$ & $3.113 \pm 1.023$ & \\
\hline Cap blanc & $0.076 \pm 0.021$ & $0.251 \pm 0.111$ & $0.020 \pm 0.002$ & \begin{tabular}{|l|}
$0.573 \pm 0.083$ \\
\end{tabular} & $1.900 \pm 0.620$ & $3.635 \pm 0.240$ & \\
\hline Imrop & $0.082 \pm 0.012$ & $0.805 \pm 0.028$ & $0.019 \pm 0.002$ & $0.352 \pm 0.008$ & $1.219 \pm 0.424$ & $0.886 \pm 0.009$ & \\
\hline $\begin{array}{l}\text { Banc } \\
\text { d'Arguin }\end{array}$ & 0.16 & 5.4 & --- & 4 & 26 & 2.90 & $\begin{array}{l}\text { (Nolting, } \\
\text { Ramkema, } \\
\& \\
\text { Everaarts, } \\
1999 \text { ) } \\
\end{array}$ \\
\hline \multicolumn{8}{|c|}{ Marocco Atlantic coast } \\
\hline \multicolumn{8}{|l|}{ Estuaries } \\
\hline Loukous & $0,15-1,60$ & $31,81-49,66$ & --- & $1,63-32,33$ & $\begin{array}{l}64,81- \\
115,27\end{array}$ & $\begin{array}{l}12564- \\
48567\end{array}$ & \multirow{5}{*}{$\begin{array}{l}\text { (Cheggour } \\
\text { et al., } \\
2001 \text { ) }\end{array}$} \\
\hline Sebou & 1,15 & --- & --- & 20 & 217 & --- & \\
\hline Bouregreg & 1,64 & --- & --- & 18,3 & 178 & --- & \\
\hline Oum Rabia & 1,45 & & & 16,2 & 222 & & \\
\hline Lagoon & 3.6 & $18-92$ & --- & juil-65 & $25-221$ & --- & \\
\hline \multicolumn{8}{|c|}{ Sénégal } \\
\hline Dakar coast & 0.65 & --- & --- & 9.98 & 15.5 & 8.5 & $\begin{array}{l}\text { (Diop et } \\
\text { al., 2012) }\end{array}$ \\
\hline \multicolumn{8}{|c|}{ Spain } \\
\hline $\begin{array}{l}\text { Southern } \\
\text { Atlantic } \\
\text { Coast }\end{array}$ & 0.38 & 16.09 & 0.20 & 30.09 & 173.45 & --- & $\begin{array}{l}\text { (Usero, } \\
\text { Morillo, } \\
\text { \& Gracia, } \\
\text { 2005) }\end{array}$ \\
\hline
\end{tabular}

\subsection{Toxicity assessment}

Sediment contamination and contaminant bioavailability were assessed using the sediment quality guideline values recommended by the United States Protection Agency(USEPA, 2014) and the Standard Canadian Interim Marine Sediment Quality(ISQG, 1995). The concentrations of the heavy metals analyzed in the sediments were compared with the thresholds levels (ERL, ERM, PEL, LAL and HAL) for adverse effects of these metals on the biota in the study area. 
For an assessment of the environmental aspects of the sediments analyzed and their possible effects on aquatic life in the coastal fringe of the Lévrier bay, it was necessary to use the reference values or standards in relation to the obtained results.

Table 5.

EPA guidelines for sediments, comparison of standard concentrations $\left(\mathrm{mg}^{-1} \mathrm{Kg}\right)$ for threshold impact of pollutants with sediments of the sampling sites

\begin{tabular}{|c|l|l|l|l|l|l|c|}
\hline \multicolumn{3}{|c|}{ USEPA guidelines } & \multicolumn{5}{l|}{ Studied sites (Lévrier bay) } \\
\hline & $\begin{array}{l}\text { No } \\
\text { polluted }\end{array}$ & $\begin{array}{l}\text { Moderetely } \\
\text { polluted }\end{array}$ & $\begin{array}{l}\text { Heavly } \\
\text { polluted }\end{array}$ & COMECA & $\begin{array}{l}\text { Baie de } \\
\text { l'Etoile }\end{array}$ & Cap Blanc & IMROP \\
\hline $\mathrm{Cd}$ & - & - & $>6$ & $0,090 \pm 0,018$ & $0,130 \pm 0,070$ & $0,076 \pm 0,021$ & $0,082 \pm 0,012$ \\
\hline $\mathrm{Pb}$ & $<40$ & $40-60$ & $>60$ & $1,671 \pm 0,534$ & $1,000 \pm 0,400$ & $0,251 \pm 0,111$ & $0,805 \pm 0,028$ \\
\hline $\mathrm{Hg}$ & $<1,0$ & - & $>1,0$ & $0,016 \pm 0,002$ & $0,017 \pm 0,002$ & $0,020 \pm 0,002$ & $0,019 \pm 0,002$ \\
\hline $\mathrm{Cu}$ & $<25$ & $25-50$ & $>50$ & $0,084 \pm 0,003$ & $0,590 \pm 0,007$ & $0,573 \pm 0,083$ & $0,352 \pm 0,008$ \\
\hline $\mathrm{Zn}$ & $<90$ & $90-200$ & $>200$ & $1,349 \pm 0,011$ & $1,283 \pm 0,045$ & $1,900 \pm 0,620$ & $1,219 \pm 0,424$ \\
\hline
\end{tabular}

The concentration of the elements studied $(\mathrm{Cd}, \mathrm{Pb}, \mathrm{Hg}, \mathrm{Cu}$ and $\mathrm{Zn})$ were evaluated by comparison with the United States Protection Agency(USEPA, 2014), sediment quality guideline values (Table 5), which shows that sediments from all sites sampled in this study were considered unpolluted. The comparison of metal concentrations analyzed in this study with the ERL, ERM, ISQG and PEL, LAL and HAL guideline values are presented in Table 6.

The overall analysis (Table 6) shows that the $\mathrm{Cu}, \mathrm{Zn}, \mathrm{Cd}$ and $\mathrm{Pb}$ concentrations are lower than all the guide values given above. Therefore, these elements cannot cause adverse effects on the biota of the study area.

Based on guideline values mentioned, a sample may cause a toxic effect once the concentration of one of the metals analysed reaches or exceeds ERL and ISQG limit values(Bakan \& Özkoç, 2007). Thus, the guide values of four metals $(\mathrm{Cd}, \mathrm{Cu}, \mathrm{Pb}$ and $\mathrm{Zn}$ ), presented in the Table 6 mentioned above, were used as a reference to illustrate the quality of the samples studied.

For the $\mathrm{Hg}$ and $\mathrm{Al}$ analyzed and in the absence of guide values, their possible effects on aquatic life have not been verified. In addition, these values have been applied by many authors in environmental studies. As an example, in the work done by Caeiro et al, in 2005 on the analysis of elements $\mathrm{Cd}, \mathrm{Cu}, \mathrm{Pb}, \mathrm{Cr}, \mathrm{Hg}, \mathrm{Al}, \mathrm{Zn}$ and $\mathrm{As}$ in the samples of sediments harvested from the estuary Sado at Portugal, 3\% of the samples analyzed could have significant effects on marine organisms while $47 \%$ could have moderate effects.

Bakan et al, in 2007 applied the guideline values to evaluate the impact of heavy metals $(\mathrm{Cu}, \mathrm{Zn}, \mathrm{M}$. Cr. $\mathrm{Cd}$. Pb. and $\mathrm{Ni}$ ) in surface sediments from the Turkish coast of the Black Sea on biota. These authors confirmed that the values obtained are generally low to moderate and therefore posed no threat to biota. Pedro et al (2008), carried out a study concerning the effects of certain metals $(\mathrm{Cd}, \mathrm{Co}, \mathrm{Cr}, \mathrm{Cu}, \mathrm{Hg}, \mathrm{Ni}, \mathrm{Pb}$ and $\mathrm{Zn}$ ) on the Tagus estuary in Portugal. Their study showed that the metals analyzed had only a weak effect. 
Table 6.

Comparison of standard concentrations for threshold impact of pollutants with sediments of the studied sites (mg/kg DW).

\begin{tabular}{|c|c|c|c|c|c|}
\hline Standard & & Zn & $\mathrm{Cu}$ & $\mathbf{P b}$ & Cd \\
\hline NOAA sediment quality & ERM & 410 & 270 & 218 & 9.6 \\
\hline $\begin{array}{l}\text { (Long, Macdonald, Smith, } \\
\text { \& Calder, 1995) }\end{array}$ & ERL & 150 & 34 & 46.7 & 1.2 \\
\hline \multirow{2}{*}{$\begin{array}{l}\text { Canada environment } \\
\text { (CCME, 1999) }\end{array}$} & PEL & 271 & 108 & 112 & 4.2 \\
\hline & ISOGS & 124 & 18.7 & 30.2 & 0.7 \\
\hline \multirow{2}{*}{ (USEPA, 2002) } & LAL & 5 & 2 & 2 & 0.07 \\
\hline & HAL & 410 & 270 & 218 & 9.6 \\
\hline \multirow{4}{*}{ Sediment of the study area } & COMECA & $1.349 \pm 0.011$ & $0.084 \pm 0.003$ & $1.671 \pm 0.534$ & $0.090 \pm 0.018$ \\
\hline & $\begin{array}{l}\text { Baie de } \\
\text { l'Etoile }\end{array}$ & $1.283 \pm 0.045$ & $0.590 \pm 0.007$ & $1.000 \pm 0.400$ & $0.130 \pm 0.070$ \\
\hline & Cap Blanc & $1.900 \pm 0.620$ & $0.573 \pm 0.083$ & $0.251 \pm 0.111$ & $0.076 \pm 0.021$ \\
\hline & IMROP & $1.219 \pm 0.424$ & $0.352 \pm 0.008$ & $0.805 \pm 0.028$ & $0.082 \pm 0.012$ \\
\hline
\end{tabular}

NOAA: National Oceanic and Atmospheric Administration (USA), ERL: concentration below which adverse effect would be rarely observed, ERM: concentration where biological effects may occur, ISQG: quality guideline value, PEL: concentration above which adverse effects are expected to occur frequently.

\subsection{Quality assessment with pollution indices}

\subsubsection{Spatial variation in trace metal-based indices}

The use of the many indices and approaches is recommended for a better assessment of the quality of sediments and their development. They are fast and relatively simple to apply (Kwon and Lee., 1998). The use of these tools gives more performance and confidence in decisions about human health and marine and coastal ecosystems (Caeiro et al., 2005). For the calculation of certain indices, we have also used the average values of the metallic elements in the Earth's crust recommended by Taylor (1964) as background values. These average values are recent and calculated from several previous studies. In addition, these values are similar to those proposed by the authors (Turekian \& Wedepohl, 1961; Wedepohl, 1995). Indices for elements in the sediments were calculated using $\mathrm{Al}$ as a reference element(Turekian \& Wedepohl, 1961). Al is a reliable indicator of the contribution of terrestrial and crust-derived materials (Ackermann., 1980; Chester., 2000; Lide., 2003) to estimate the anthropogenic impact on sediments and to differentiate between the anthropogenic and natural sources of metals(Sinex \& Helz, 1981; Sutherland, 
2000). Results of pollution indices (i.e. EF, Igeo, QoC(\%), CF, SPI, PLI, CD and PERI) are presented in Tables 7, 8 .

The Enrichment Factor (EF) was initially developed to study the origin of the elements in the different compartments of the sea environment(Duce, Hoffman, \& Zoller, 1975; Zoller, W. H, Hoffmann, G. L, \& Duce, R. A, 1974), but it was gradually developed and expanded to other areas such as soils, lake sediments, tailings, etc. The enrichment factor (EF) ranged from $0.88 \pm 0.04$ to $3.44 \pm 0.12$ for $\mathrm{Cd}$, from $0.07 \pm 0.02$ to $0.91 \pm 0.03$ for $\mathrm{Pb}$, from $0.02 \pm 0.01$ to 0.06 for $\mathrm{Cu}$ and from 0.05 to $0.19 \pm 0.02$ for $\mathrm{Zn}$. The $\mathrm{EF}$ for $\mathrm{Pb}, \mathrm{Cu}$ and $\mathrm{Zn}$ were $<1$ in surface sediments of all sampling sites and for $\mathrm{Cd}$ at Cap Blanc, which denotes "no enrichement" by these trace metals (Table 7). The EF values at COMECA and Baie de l'Etoile for Cd were $1<\mathrm{EF}<3$ which indicated a "low enrichment". The EF values for Cd in sediments at IMROP were $3<\mathrm{EF}<5$ which indicated a "moderate enrichment". The geoaccumulation index (Igeo) is used to evaluate heavy metal pollution in sediments (Muller., 1979, Banat et al., 2005).The results of the geoaccumulation factor (Igeo) of all metals analyzed are shown in Table 7. Igeo values of trace metals studied in sediments were less than 0 in all sampling sites, so they are classified as 'uncontaminated' (Table 7). The contamination factor (CF), which describes the contamination by a given toxic substance in a basin(Hakanson, 1980), is also used to assess contamination levels in relation to average concentrations of the respective trace metals in the environment i.e. sediment to the measured background values from previous studies with similar geological origin or uncontaminated sediments(Sutherland, 2000; Tijani, Jinno, \& Yoshinari Hiroshiro, 2004; Uriah \& Shehu, 2014). The contaminant factor (CF) ranged from $0.380 \pm 0.030$ to $0.650 \pm 0.050$ for $\mathrm{Cd}$, from $0.031 \pm 0.040$ to $0.209 \pm 0.030$ for $\mathrm{Pb}$, from 0.002 to 0.011 for $\mathrm{Cu}$, from 0.018 to $0.027 \pm 0.007$ for $\mathrm{Zn}$ and from 0.011 to $0.044 \pm 0.003$ for Al. The $\mathrm{CF}$ values for all elements analysed were $<1$ in surface sediments of all sampling sites, which indicates a "low contamination" by these trace metals (Table 8). Negative Igeo values and positive CF values suggest that the metal was imported by human activities, but that the metal in question has not yet reached the threshold of pollution due to the dilution in coarse sediments(Bhutiani, Kulkarni, Khanna, \& Gautam, 2017; Oliveira, Palma, \& Valença, 2011) or caused by relatively low levels of contamination of some metals in some cores and the background variability factor (1.5) in the Igeo equation(Abrahim \& Parker, 2007; Müller, G., 1979). Quantification of contamination (QoC (\%)) represents the lithogenic metal(Asaah, Victor A., Akinlolu, F, \& Suh, Cheo E, 2006). The QoC values for heavy metals $\mathrm{Cd}, \mathrm{Pb}, \mathrm{Hg}, \mathrm{Cu}, \mathrm{Zn}$ and $\mathrm{Al}$ were negative for all sampling sites, indicating that anthropogenic activities are not the causes of contamination at the majority sites in the study area(Table 7). The pollution load index (PLI) provides more complete information on the toxicity of the metals studied in the respective samples analyzed (Bhutiani et al., 2017; Ghaleno, 2015; Tomlinson, Wilson, Harris, \& Jeffrey, 1980; Yang, Xu, Liu, He, \& Long, 2011). The pollution load index (PLI) ranged from $0.124 \pm 0.005$ to $0.166 \pm 0.013$ (Table 8). The PLI values in sediments of all studied sites were $<1$ which indicates that there was no metal pollution (Table 8). The PLI followed the order of the Baie de l'Etoile> Cap Blanc > COMECA > IMROP. The Sediment Pollution Index (SPI) is defined as the linear sum of the metal enrichment factors weighted by their respective toxicity weights. These metal toxicity weights are based on their different relative toxicity and are inversely proportional to the lithogenic limits of the average shale. This is based on the fact that metal concentrations in unpolluted sediments should not exceed average shale values (Singh et al., 2002). The Sediment Pollution Index (SPI) ranged from 0.856 to 3.363 in surface sediments of the study area (Table 8). The SPI values at COMECA, Baie de l'Etoile and 
Cap Blanc were $0<\mathrm{SPI}<2$ which showed "natural sediments". The SPI value at IMROP was $2<\mathrm{SPI}<5$ indicated "low polluted sediments". The contamination degree $\left(\mathrm{C}_{\mathrm{d}}\right)$ is the sum of all contamination factors, which provides information about all contamination in a particular sampling location(Singovszka, Balintova, Demcak, \& Pavlikova, 2017). The contamination degree $\left(\mathrm{C}_{\mathrm{d}}\right)$ ranged from $0.688 \pm 0.052$ to $0.817 \pm 0.143$ (Table 8). The $\mathrm{C}_{\mathrm{d}}$ values in sediments of all sampling sites were $<6$ which indicated a "low degree of contamination". The Potential Ecological Risk Index (PERI) is commonly used as a tool for the diagnosis of heavy metal pollution in sediments(Hakanson, 1980), as it takes into account the levels and toxicities of heavy metals(Ntakirutimana, Du, Guo, Gao, \& Huang, 2013). However, risk levels may be overstated because of the use of total content rather than species-related data.The geo-accumulation index shows the level of enrichment of heavy metals without taking into account the biological effect of heavy metals, while the potential ecological risk index (PERI) includes the toxicity of heavy metals to mitigate this deficiency. Therefore, combining these two evaluation methods can make the assessment results of the heavy metal pollution more comprehensive and rational(Yu et al., 2017). The potential ecological risk index (PERI) varied between 21.50 and 28.14 in the study area (Table 8). PERI values were $<90$ at all sampling sites, then according to Hakanson (1980) these sites were classified as being at "low ecologic risk". The PERI ranking order was Baie de l'Etoile> COMECA > IMROP > Cap Blanc (Table 8). Such indices offer useful information, provided that their limitations are recognized. So, the overall results of this study showed the lowest levels of heavy metal contamination in the sediments at the Lévrier bay. The systematic monitoring and evaluation of these marine and coastal ecosystems is a priority for safeguarding ecological security .The data in this study provide a basis for future investigations of trace metal pollution and its possible impacts on the sensitive ecosystems.

Table 7.

Mean values $( \pm$ SEM) of heavy for metals enrichiment factor $(\mathrm{EF})$, geoaccumulation index (Igeo) and quantification of contamination $(\mathrm{QoC}(\%))$ in surface sediment at each sampling site along the Lévrier bay.

\begin{tabular}{|c|c|c|c|c|c|c|c|c|c|c|c|c|c|c|c|}
\hline \multirow{2}{*}{$\begin{array}{l}S \\
\text { it } \\
\text { e }\end{array}$} & \multicolumn{3}{|l|}{ Cd } & \multicolumn{3}{|l|}{$\mathbf{P b}$} & \multirow{2}{*}{$\begin{array}{l}\text { Hg } \\
\text { Qo } \\
\text { C( } \\
\%)\end{array}$} & \multicolumn{3}{|l|}{$\mathbf{C u}$} & \multicolumn{3}{|l|}{$\mathbf{Z n}$} & \multicolumn{2}{|l|}{$\mathrm{Al}$} \\
\hline & $\mathrm{EF}$ & Igeo & $\begin{array}{l}\text { Qo } \\
\text { C( } \\
\%)\end{array}$ & $\mathrm{EF}$ & Igeo & $\begin{array}{l}\text { Qo } \\
\text { C( } \\
\%)\end{array}$ & & $\mathrm{EF}$ & Igeo & $\begin{array}{l}\text { Qo } \\
\text { C(\% } \\
)\end{array}$ & $\mathrm{EF}$ & Igeo & $\begin{array}{l}\text { Qo } \\
\text { C( } \\
\%)\end{array}$ & Igeo & $\begin{array}{l}\text { Qo } \\
\text { C( } \\
\%)\end{array}$ \\
\hline $\begin{array}{l}\mathrm{C} \\
\mathrm{O}\end{array}$ & $\begin{array}{l}3.44 \\
\pm 0.1 \\
2\end{array}$ & $\begin{array}{l}- \\
2.33 \\
\pm 0.3 \\
5\end{array}$ & $\begin{array}{l}- \\
211 \\
.69\end{array}$ & $\begin{array}{l}0.91 \\
\pm 0.0 \\
3\end{array}$ & $\begin{array}{l}- \\
3.36 \\
\pm 0.3 \\
1\end{array}$ & $\begin{array}{l}- \\
541 \\
.42\end{array}$ & $\begin{array}{l}- \\
383 \\
.75\end{array}$ & 0.06 & $\begin{array}{l}- \\
9.19 \\
\pm 0.4 \\
8\end{array}$ & $\begin{array}{l}- \\
315 \\
12.9 \\
1\end{array}$ & $\begin{array}{l}0.19 \\
\pm 0.0 \\
2\end{array}$ & $\begin{array}{l}- \\
6.50 \\
\pm 0.1 \\
6\end{array}$ & $\begin{array}{l}- \\
591 \\
3.7 \\
7\end{array}$ & $\begin{array}{l}2.67 \\
\pm 1.5 \\
4\end{array}$ & $\begin{array}{l}- \\
260 \\
9.4 \\
7\end{array}$ \\
\hline $\begin{array}{l}\text { B } \\
\text { E }\end{array}$ & $\begin{array}{l}1.24 \\
\pm 0.1 \\
9\end{array}$ & $\begin{array}{l}- \\
1.97 \\
\pm 0.4 \\
4\end{array}$ & $\begin{array}{l}- \\
165 \\
.19\end{array}$ & $\begin{array}{l}0.57 \\
\pm 0.0 \\
6\end{array}$ & $\begin{array}{l}- \\
5.34 \\
\pm 0.9 \\
8\end{array}$ & $\begin{array}{l}- \\
136 \\
0.6 \\
3\end{array}$ & $\begin{array}{l}- \\
288 \\
.90\end{array}$ & 0.00 & $\begin{array}{l}- \\
7.11 \\
\pm 0.0 \\
2\end{array}$ & $\begin{array}{l}- \\
919 \\
8.51\end{array}$ & 0.05 & $\begin{array}{l}- \\
6.19 \\
\pm 0.1 \\
0\end{array}$ & $\begin{array}{l}- \\
547 \\
7.6 \\
5\end{array}$ & $\begin{array}{l}- \\
2.66 \\
\pm 1.5 \\
4\end{array}$ & $\begin{array}{l}- \\
277 \\
1.3 \\
5\end{array}$ \\
\hline $\begin{array}{l}\text { C } \\
\text { B }\end{array}$ & $\begin{array}{l}1.75 \\
\pm 0.0 \\
5\end{array}$ & $\begin{array}{l}- \\
2.15 \\
\pm 0.2 \\
0\end{array}$ & $\begin{array}{l}- \\
188 \\
.29\end{array}$ & $\begin{array}{l}0.32 \\
\pm 0.1 \\
0\end{array}$ & $\begin{array}{l}- \\
5.06 \\
\pm 0.4 \\
2\end{array}$ & $\begin{array}{l}- \\
182 \\
6.7 \\
9\end{array}$ & $\begin{array}{l}- \\
314 \\
.24\end{array}$ & 0.03 & $\begin{array}{l}- \\
7.52 \\
\pm 0.2 \\
1\end{array}$ & $\begin{array}{l}- \\
117 \\
43.8 \\
8\end{array}$ & $\begin{array}{l}0.05 \\
\pm 0.0 \\
1\end{array}$ & $\begin{array}{l}- \\
6.75 \\
\pm 0.5 \\
6\end{array}$ & $\begin{array}{l}- \\
567 \\
7.3 \\
0\end{array}$ & $\begin{array}{l}- \\
2.54 \\
\pm 1.4 \\
7\end{array}$ & $\begin{array}{l}- \\
216 \\
4.1 \\
0\end{array}$ \\
\hline $\begin{array}{l}\text { I } \\
\text { M }\end{array}$ & $\begin{array}{l}0.88 \\
\pm 0.0 \\
4\end{array}$ & $\begin{array}{l}- \\
2.31 \\
\pm 0.4 \\
9\end{array}$ & $\begin{array}{l}- \\
177 \\
.46\end{array}$ & $\begin{array}{l}0.07 \\
\pm 0.0 \\
2\end{array}$ & $\begin{array}{l}- \\
4.82 \\
\pm 0.5 \\
8\end{array}$ & $\begin{array}{l}- \\
143 \\
5.7 \\
7\end{array}$ & $\begin{array}{l}- \\
305 \\
.47\end{array}$ & $\begin{array}{l}0.02 \\
\pm 0.0 \\
1\end{array}$ & $\begin{array}{l}- \\
8.02 \\
\pm 0.1 \\
2\end{array}$ & $\begin{array}{l}- \\
202 \\
14.2 \\
3\end{array}$ & $\begin{array}{l}0.06 \\
\pm 0.0 \\
2\end{array}$ & $\begin{array}{l}- \\
6.16 \\
\pm 0.3 \\
2\end{array}$ & $\begin{array}{l}- \\
469 \\
2.2 \\
3\end{array}$ & $\begin{array}{l}- \\
3.53 \\
\pm 2.0 \\
4\end{array}$ & $\begin{array}{l}- \\
919 \\
0.6 \\
9\end{array}$ \\
\hline
\end{tabular}


Table 8.

Mean values $( \pm$ SEM) of heavy metals for Contaminant factor $(\mathrm{CF})$, Sediment Pollution Index (SPI), pollution load index (PLI), contamination degree $\left(C_{d}\right)$ and potential ecological risk index (PERI) in surface sediments at all sampling sites from the Lévrier bay.

\begin{tabular}{|c|c|c|c|c|c|c|c|c|c|}
\hline \multirow{2}{*}{ Site } & \multicolumn{5}{|c|}{ CF } & \multirow{2}{*}{ SPI } & \multirow{2}{*}{ PLI } & \multirow{2}{*}{$\mathbf{C}_{d}$} & \multirow{2}{*}{$\begin{array}{c}\text { PER } \\
\text { I }\end{array}$} \\
\hline & Cd & $\mathbf{P b}$ & $\mathbf{C u}$ & $\mathbf{Z n}$ & Al & & & & \\
\hline $\begin{array}{c}\text { COMEC } \\
\mathrm{A}\end{array}$ & $\begin{array}{c}0.450 \pm 0.0 \\
50\end{array}$ & $\begin{array}{c}0.209 \pm 0.0 \\
30\end{array}$ & 0.002 & 0.019 & $\begin{array}{c}0.037 \pm 0.0 \\
02\end{array}$ & $\begin{array}{c}3.36 \pm 0 . \\
12\end{array}$ & $\begin{array}{c}0.133 \pm 0.0 \\
01\end{array}$ & $\begin{array}{c}0.726 \pm 0.1 \\
08\end{array}$ & $\begin{array}{c}21.6 \\
5\end{array}$ \\
\hline $\begin{array}{l}\text { Baie de } \\
\text { l'Etoile }\end{array}$ & $\begin{array}{c}0.650 \pm 0.0 \\
50\end{array}$ & $\begin{array}{c}0.125 \pm 0.0 \\
50 \\
\end{array}$ & 0.011 & 0.018 & $\begin{array}{c}0.038 \pm 0.0 \\
04\end{array}$ & $\begin{array}{c}1.22 \pm 0 . \\
19\end{array}$ & $\begin{array}{c}0.166 \pm 0.0 \\
13\end{array}$ & $\begin{array}{c}0.817 \pm 0.1 \\
43\end{array}$ & $\begin{array}{c}28.1 \\
4\end{array}$ \\
\hline $\begin{array}{c}\text { Cap } \\
\text { Blanc }\end{array}$ & $\begin{array}{c}0.381 \pm 0.0 \\
60 \\
\end{array}$ & $\begin{array}{c}0.031 \pm 0.0 \\
40\end{array}$ & $\begin{array}{c}0.010 \pm 0.0 \\
02\end{array}$ & $\begin{array}{c}0.027 \pm 0.0 \\
07\end{array}$ & $\begin{array}{c}0.044 \pm 0.0 \\
03\end{array}$ & $\begin{array}{c}1.71 \pm 0 . \\
05\end{array}$ & $\begin{array}{c}0.139 \pm 0.0 \\
08\end{array}$ & $\begin{array}{c}0.688 \pm 0.0 \\
52\end{array}$ & $\begin{array}{c}21.5 \\
0\end{array}$ \\
\hline IMROP & $\begin{array}{c}0.380 \pm 0.0 \\
30\end{array}$ & $\begin{array}{c}0.101 \pm 0.0 \\
01\end{array}$ & 0.006 & $\begin{array}{c}0.021 \pm 0.0 \\
03\end{array}$ & 0.011 & $\begin{array}{c}0.86 \pm 0 . \\
04\end{array}$ & $\begin{array}{c}0.124 \pm 0.0 \\
05\end{array}$ & $\begin{array}{c}0.692 \pm 0.1 \\
06\end{array}$ & $\begin{array}{c}21.9 \\
1\end{array}$ \\
\hline
\end{tabular}

\section{CONCLUSION}

The physicochemical parameters collected from superficial sediment in the Lévrier bay vary little from one site to another and do not show an apparent accumulation of heavy metals in the samples analysed. The heavy metal concentrations in superficial sediments varied between sampling sites, with IMROP showing the highest levels of $\mathrm{Zn}$ recorded and the lowest values of $\mathrm{Hg}$ compared to all other sampling sites. In contrast, no significant seasonal variation between the four sampling sites was found. It can be seen that the mean concentrations of all studied heavy metals in this study were much lower than those in other areas along the NW African coast. All sampling sites that we studied were considered unpolluted by $\mathrm{Cd}, \mathrm{Pb}, \mathrm{Hg}, \mathrm{Cu}$ and $\mathrm{Zn}$, when the chemical contamination in the sediments was compared with international standards. Our findings showed that in the overall analysis of the sediments concentrations of $\mathrm{Cu}, \mathrm{Zn}, \mathrm{Cd}$ and $\mathrm{Pb}$ were below the corresponding guides values of the ISOGS, ERM, PEL, LAL, HAL, indicating no harmful effect on the biota in the study area. The ecological health risk assessment of trace metals using chemical pollution indices revealed none to moderate enrichment for heavy metals analysed in surface sediments (Enrichment factor), uncontaminated sampling sites (Geoaccumulaion index), low contamination (Contamination factor), and natural to low polluted sediments (Sediment Pollution Index). The pollution load index (PLI) at all sampling sites indicates no pollution, and the contamination degree of pollution $\left(\mathrm{C}_{\mathrm{d}}\right)$ values in sediments of all sampling showed a low degree of contamination. According to mean values of the potential ecological risk index (PERI), all sampling sites were classified as being at low ecologic risk. The quantification factor of contamination (QoC) indicated that anthropogenic activities were not the main cause of contamination at the majority sites in the study area. Our findings should raise the awareness of the contamination status at the Lévrier bay's coast, and provide a valuable benchmark for future comparisons in the area. They are of great importance for the design of long-term management and good governance policies of marine and coastal areas of Mauritania. Finally, it is important that local authorities act responsibly and enforce existing laws and regulations to protect marine and coastal biodiversity. Without a doubt, this study will contribute to the limited knowledge of sediment contamination by heavy metals in the Lévrier bay and the sub-region.

\section{ACKNOWLEDGEMENTS}

This study results from a collaboration between the University of Nouakchott Al Aasriya (Mauritania), Abdel Malek Essaadi University (Morocco), Mauritanian Institute of Oceanographic and Fisheries Research (IMROP) and the National Office of Sanitary Inspection of Fishery Products 
and Aquaculture (ONISPA). The authors would like to devote a special thanks to these institutions for courtesy, kindness and help. We also would like to thank Rouane Omar Hassane from the Laboratory of Environmental Monitoring Network (LRSE) of Ahmed Ben Bella University 1(Algéria) for his support. The reason why a large number of authors (7) contributed to the realization of this manuscript takes place in their specialization as well as their respective roles in the different parts of this document.

\section{RE F E R E N C ES}

Abrahim, G. M. S., \& Parker, R. J. (2007). Assessment of heavy metal enrichment factors and the degree of contamination in marine sediments from Tamaki Estuary, Auckland, New Zealand. Environmental Monitoring and Assessment, 136(1-3), 227-238. https://doi.org/10.1007/s10661007-9678-2

Alharbi, T., \& El-Sorogy, A. (2017). Assessment of metal contamination in coastal sediments of AlKhobar area, Arabian Gulf, Saudi Arabia. Journal of African Earth Sciences, 129, 458-468. https://doi.org/10.1016/j.jafrearsci.2017.02.007

Asaah, Victor A., Akinlolu, F, \& Suh, Cheo E. (2006). Heavy metal concentrations and distribution in surface soils of the Bassa Industrial Zone 1, Douala, Cameroon. Arabian Journal for Science and Engineering, 31, 147-158.

Bakan, G., \& Özkoç, H. B. (2007). An ecological risk assessment of the impact of heavy metals in surface sediments on biota from the mid-Black Sea coast of Turkey. International Journal of Environmental Studies, 64, 45-57.

Bastami, K. D., Afkhami, M., Mohammadizadeh, M., Ehsanpour, M., Chambari, S., Aghaei, S., ... Baniamam, M. (2015). Bioaccumulation and ecological risk assessment of heavy metals in the sediments and mullet Liza klunzingeri in the northern part of the Persian Gulf. Marine Pollution Bulletin, 94(1-2), 329-334. https://doi.org/10.1016/j.marpolbul.2015.01.019

Bhutiani, R., Kulkarni, D. B., Khanna, D. R., \& Gautam, A. (2017). Geochemical distribution and environmental risk assessment of heavy metals in groundwater of an industrial area and its surroundings, Haridwar, India. Energy, Ecology and Environment, 2(2), 155-167. https://doi.org/10.1007/s40974-016-0019-6

Caeiro, S., Costa, M. H., Ramos, T. B., Fernandes, F., Silveira, N., Coimbra, A., ... Painho, M. (2005). Assessing heavy metal contamination in Sado Estuary sediment: An index analysis approach. Ecological Indicators, 5(2), 151-169. https://doi.org/10.1016/j.ecolind.2005.02.001

CCME. (1999). Canadian environmentalquality guidelines.Available online at http://ceqgrcqe.ccme.ca/.

Cheggour, M., Chafik, A., Langston, W. J., Burt, G. R., Benbrahim, S., \& Texier, H. (2001). Metals in sediments and the edible cockle Cerastoderma edule from two Moroccan Atlantic lagoons: Moulay Bou Selham and Sidi Moussa. Environmental Pollution, 115(2), 149-160.

Chouba, L., Kraiem, M., Njimi, W., Tissaoui, C. H., Thompson, J. R., \& Flower, R. J. (2007). Seasonal variation of heavy metals $(\mathrm{Cd}, \mathrm{Pb}$ and $\mathrm{Hg})$ in sediments and in mullet, Mugil cephalus (Mugilidae), from the Ghar El Melh Lagoon (Tunisia). Transitional Waters Bulletin, 1(4), 4552.

Chouba, Lassaad, \& Mzougui-Aguir, N. (2006). Les métaux traces (Cd, Pb, Hg) et les hydrocarbures totaux dans les sédiments superficiels de la frange côtière du golfe de Gabès.

Diop, C., Dewaele, D., Toure, A., Cabral, M., Cazier, F., Fall, M., ... Diouf, A. (2012). Étude de la contamination par les éléments traces métalliques des sédiments cotiers au niveau des points d'évacuation des eaux usées à Dakar (Sénégal). Revue des sciences de l'eau, 25(3), 277. https://doi.org/10.7202/1013107ar

Duce, R. A., Hoffman, G. L., \& Zoller, W. H. (1975). Atmospheric trace metals at remote northern and southern hemisphere sites: pollution or natural? Science, 187(4171), 59-61. 
Ghaleno, O. R. (2015). Potential ecological risk assessment of heavy metals in sediments of water reservoir case study: Chah Nimeh of Sistan. Proceedings of the International Academy of Ecology and Environmental Sciences, 5(3), 89.

Ghasemi, S., Moghaddam, S. S., Rahimi, A., Damalas, C. A., \& Naji, A. (2018). Ecological risk assessment of coastal ecosystems: The case of mangrove forests in Hormozgan Province, Iran. Chemosphere, 191, 417-426. https://doi.org/10.1016/j.chemosphere.2017.10.047

Hakanson, L. (1980). An ecological risk index for aquatic pollution control.a sedimentological approach. Water Research, 14, 975-1001.

ISQG. (1995). InterimSedimentQuality Guidelines. Environment Canada, Ottawa, p. 9.

Izah, S. C., Bassey, S. E., \& Ohimain, E. I. (2017). Assessment of Pollution Load Indices of Heavy Metals in Cassava Mill Effluents Contaminated Soil: a Case Study of Small-scale Processors in a Rural Community in the Niger Delta, Nigeria. Bioscience Methods. https://doi.org/10.5376/bm.2017.08.0001.

Krauskopf, K. B. (1955). Sedimentary deposits or rare metals. Economic Geology $50^{\text {th }}$ aniversary volume, United States Department of the Interior Geological Survey, 411-463.

Li, F., Huang, J., Zeng, G., Yuan, X., Li, X., Liang, J., Bai, B. (2013). Spatial risk assessment and sources identification of heavy metals in surface sediments from the Dongting Lake, Middle China. Journal of Geochemical Exploration, 132, 75-83. https://doi.org/10.1016/j.gexplo.2013.05.007

Liu, Q., Wang, F., Meng, F., Jiang, L., Li, G., \& Zhou, R. (2018). Assessment of metal contamination in estuarine surface sediments from Dongying City, China: Use of a modified ecological risk index. Marine Pollution Bulletin, 126, 293-303. https://doi.org/10.1016/j.marpolbul.2017.11.017

Long, E. R., Macdonald, D. D., Smith, S. L., \& Calder, F. D. (1995). Incidence of adverse biological effects within ranges of chemical concentrations in marine and estuarine sediments. Environmental management, 19(1), 81-97.

Maigret, J. (1972). Campagne expérimentale de pêche des sardinelles et autres espèces pélagiques (Juillet 1970 - Octobre 1971). Observations concernant l'océanographie et la biologie des espèces. Laboratoire des Pêches.

Müller, G. (1979). Distribution, Enrichment and Ecological Risk Assessment of Six Elements in Bed Sediments of a Tropical River, Chottanagpur Plateau: A Spatial and Temporal Appraisal. Umsch. Wiss.Tech, 79, 778-783.

Nolting, R. F., Ramkema, A., \& Everaarts, J. M. (1999). The geochemistry of Cu, Cd, Zn, Ni and Pb in sediment cores from the continental slope of the Banc d'Arguin (Mauritania). Continental Shelf Research, 19(5), 665-691.

Ntakirutimana, T., Du, G., Guo, J., Gao, X., \& Huang, L. (2013). Pollution and Potential Ecological Risk Assessment of Heavy Metals in a Lake. Polish Journal of Environmental Studies, 22(4).

Oliveira, A., Palma, C., \& Valença, M. C. de A. (2011). Heavy metal distribution in surface sediments from the continental shelf adjacent to Nazaré canyon. Deep Sea Research Part II Topical Studies in Oceanography, 58, 2420-2432.

Ridgway, I. M., \& N.B. PRICE. (1987). Geochemical associations and post-depositional mobility of heavy metals in coastal sediments: Loch Etive, Scotland. Marine Chemistry, 21, 229 248.

Romankevich, E. A. (1984). Geochemistry of Organic Matter in the Ocean. Clean Soil Air Water, 13, 668.

Sharifinia, M., Taherizadeh, M., Namin, J. I., \& Kamrani, E. (2018). Ecological risk assessment of trace metals in the surface sediments of the Persian Gulf and Gulf of Oman: Evidence from subtropical estuaries of the Iranian coastal waters. Chemosphere, 191, 485-493. https://doi.org/10.1016/j.chemosphere.2017.10.077

Sinex, S. A., \& Helz, G. R. (1981). Regional geochemistry of trace elements in Chesapeake Bay sediments. Environmental Geology, 3(6), 315-323. 
Singovszka, E., Balintova, M., Demcak, S., \& Pavlikova, P. (2017). Metal Pollution Indices of Bottom Sediment and Surface Water Affected by Acid Mine Drainage. Metals, 7(12), 284. https://doi.org/10.3390/met7080284

Sutherland, R. A. (2000). Bed sediment-associated trace metals in an urban stream, Oahu, Hawaii. Environmental geology, 39(6), 611-627.

Tijani, M. N., Jinno, K., \& Yoshinari Hiroshiro. (2004). Environmental impact of heavy metals distribution in water and sediments of Ogunpa River, Ibadan area, southwestern Nigeria. Journal of Mining and Geology, 40, 73-83.

Tomlinson, D. L., Wilson, J. G., Harris, C. R., \& Jeffrey, D. W. (1980). Problems in the assessment of heavy-metal levels in estuaries and the formation of a pollution index. Helgol nder Meeresunters, 33, 566-575.

Turekian, K. K., \& Wedepohl, K. H. (1961). Distribution of the Elements in Some Major Units of the Earth's Crust. Geological Society of America Bulletin, 72(2), 175. https://doi.org/10.1130/00167606(1961)72[175:DOTEIS]2.0.CO;2

Uriah, L. A., \& Shehu, U. (2014). Environmental risk assessment of heavy metals content of municipal solid waste used as organic fertilizer in vegetable gardens on the Jos Plateau, Nigeria. American Journal of Environmental Protection, 3(6-2), 1-13.

USEPA. (2002). Onsite wastewater treatment systems manual. Office of Research and Development.US Environmental Protection Agency EPA/625/R-00/008.

USEPA. (2014). Sediment Sampling United States Environmental Protection Agency, Washington, DC, USA.https://www.epa.gov/sites/production/files/2015-06/ documents/SedimentSampling.pdf (Accessed 26, March 2017).

Usero, J., Morillo, J., \& Gracia, I. (2005). Heavy metal concentrations in molluscs from the Atlantic coast of southern Spain. Chemosphere, 59(8), 1175-1181. https://doi.org/10.1016/j.chemosphere.2004.11.089

Vu, C. T., Lin, C., Shern, C.-C., Yeh, G., Le, V. G., \& Tran, H. T. (2017). Contamination, ecological risk and source apportionment of heavy metals in sediments and water of a contaminated river in Taiwan. Ecological Indicators, 82, 32-42. https://doi.org/10.1016/j.ecolind.2017.06.008

Wagne, M. M. (2013). Contribution à l'étude de la qualité environnementale et sanitaire des eaux de la baie du Lévrier (Mauritanie). UNIVERSITE SIDI MOHAMED BEN ABDELLAH, Fès, Maroc.

Wagne, M. M., BRAHIM, H. O., DARTIGE, A., \& SÉFRIOUI, S. (2011). Contribution à l'étude du phytoplancton potentiellement nuisible de la baie du Lévrier (Mauritanie).

Wedepohl, K. H. (1995). The composition of the continental crust. Geochimica et cosmochimica Acta, 59(7), 1217-1232.

Yang, Q., Xu, Y., Liu, S., He, J., \& Long, F. (2011). Concentration and potential health risk of heavy metals in market vegetables in Chongqing, China. Ecotoxicology and Environmental Safety, 74(6), 1664-1669. https://doi.org/10.1016/j.ecoenv.2011.05.006

Yu, R., Hu, G., Lin, C., Yang, Q., Zhang, C., \& Wang, X. (2017). Contamination of heavy metals and isotopic tracing of $\mathrm{Pb}$ in intertidal surface sediments of Jinjiang River Estuary, SE China. Applied Geochemistry, 83, 41-49. https://doi.org/10.1016/j.apgeochem.2016.12.025

Zhang, G., Bai, J., Xiao, R., Zhao, Q., Jia, J., Cui, B., \& Liu, X. (2017). Heavy metal fractions and ecological risk assessment in sediments from urban, rural and reclamation-affected rivers of the Pearl River Estuary, China. Chemosphere, 184, 278-288. https://doi.org/10.1016/j.chemosphere.2017.05.155

Zoller, W. H, Hoffmann, G. L, \& Duce, R. A. (1974). Atmospheric concentrations and sources of trace metals at the South Pole. Science, 183(4121), 198-200. 